\title{
Karakterisasi Carboxymethyl Cellulose Sodium (Na-CMC) dari Selulosa Eceng Gondok (Eichhornia crassipes (Mart.) Solms.) yang Tumbuh di Daerah Jatinangor dan Lembang
}

\author{
Wiwiek Indriyati, Ida Musfiroh, Rembulan Kusmawanti, Sriwidodo, Aliya Nur Hasanah \\ Fakultas Farmasi, Universitas Padjadjaran, Jatinangor, Sumedang
}

\begin{abstract}
Abstrak
Eceng gondok (Eichhornia crassipes (Mart.) Solms.) memiliki kandungan selulosa yang tinggi sehingga berpotensi sebagai sumber bahan baku pembuatan carboxymethyl cellulose sodium (Na$\mathrm{CMC}$ ). Kandungan $\alpha$-selulosa dapat mempengaruhi kualitas Na-CMC. Penelitian ini dilakukan untuk mengetahui karakteristik Na-CMC yang dihasilkan dari sintesis alfa selulosa eceng gondok dari dua wilayah tempat tumbuh yang berbeda yaitu Jatinangor dan Lembang Jawa Barat. Metode yang dilakukan meliputi isolasi $\alpha$-selulosa menggunakan natrium hidroksida $30 \%$, sintesis $\mathrm{Na}$ CMC melalui tahap alkalinasi menggunakan natrium hidroksida $40 \%$ dan karboksimetilasi dengan natrium monokloroasetat; penambahan crosslinker epiklorohidrin; dan karakterisasi Na-CMC. Hasil isolasi $\alpha$-selulosa dan sintesis $\mathrm{Na} \mathrm{CMC}$ dari eceng gondok Jatinangor dan Lembang yaitu kadar $\alpha$-selulosa masing-masing $76,53 \%$ dan $71,35 \%$; rendemen Na-CMC sebesar $96,87 \%$ dan $85,03 \%$. Hasil karakterisasi Na-CMC menunjukkan adanya perbedaan yang signifikan pada nilai WHC (Water Holding Capacity) namun tidak terdapat perbedaan pada nilai OHC (Oil Holding Capacity) dari Na-CMC hasil sintesis dari tanaman eceng gondok yang tumbuh di Jatinangor dan Lembang.
\end{abstract}

Kata kunci: Eceng gondok, $\alpha$-Selulosa, Na-CMC, Karakterisasi, WHC, OHC

\section{Characterization of Carboxymethyl Cellulose Sodium (Na-CMC) from Water Hyacinth (Eichhornia crassipes (Mart.) Solms) Cellulose) Growing in Jatinangor and Lembang}

\begin{abstract}
Water hyacinth (Eichhornia crassipes (Mart.) Solms.) has a high cellulose content so it is potential source for sodium carboxymethyl cellulose (Na-CMC) synthesis. Cellulose content has effect for Na-CMC quality. This study aimed to perform the characteristics of Na-CMC synthesized from water hyacinth that different growth place, in Jatinangor and Lembang. The methods was included alfa cellulose isolation using 30\% sodium hydroxide; synthesis of $\mathrm{Na}-\mathrm{CMC}$ through alkalination phase using $40 \%$ sodium hydroxide and carboxymethylation with sodium monochloroacetate; the addition of epichlorohydrin crosslinker; and characterization of $\mathrm{Na}-\mathrm{CMC}$. The result of $\alpha$-cellulose isolation and $\mathrm{Na} \mathrm{CMC}$ synthesized from Jatinangor and Lembang water hyacinth were $76.53 \%$ and $71.35 \%$, respectively; $\mathrm{Na}-\mathrm{CMC}$ yield from synthesis were $96.87 \%$ and $85.03 \%$. The results of $\mathrm{Na}$ CMC characterization showed significant differences in WHC (Water Holding Capacity) from both places but not significant in $\mathrm{OHC}$ (Oil Holding Capacity) value.
\end{abstract}

Keywords: Water Hyacinth, $\alpha$-cellulose, Na-CMC, Characterization, WHC, OHC 


\section{Pendahuluan}

Eceng gondok (Eichhornia crassipes (Mart.) Solms) diketahui mengandung selulosa yang cukup tinggi yaitu sebesar $66.87 \% .{ }^{1}$ Kandungan selulosa yang cukup tinggi menjadikan eceng gondok berpotensi sebagai sumber bahan baku pembuatan carboxymethyl cellulose sodium (NaCMC).

$\mathrm{Na}-\mathrm{CMC}$ telah digunakan secara luas di bidang farmasi sebagai eksipien. Na-CMC banyak digunakan sebagai emulsifying agent, gelling agent dan tablet binder. ${ }^{2}$

Water Holding Capacity (WHC) dan Oil Holding Capacity (OHC) merupakan parameter penilaian kualitas yang lazim digunakan untuk Na-CMC. Nilai WHC dan $\mathrm{OHC}$ akan berpengaruh pada viskositas dari Na-CMC yang dihasilkan. ${ }^{3}$

Penelitian sebelumnya yang dilakukan Musfiroh dkk (2013) menunjukkan bawha Na-CMC yang disintesis dari selulosa eceng gondok yang tumbuh di daerah Jatinangor memiliki kekurangan pada nilai WHC dan OHC dibandingkan dengan NaCMC baku. ${ }^{1}$ Selanjutnya pada tahun 2015 Nurhasanah dkk, menyatakan bahwa NaCMC yang disintesis dari selulosa tanaman eceng gondok dari Sungai di Kecamatan Jatinangor dengan crosslink menggunakan epiklorohidrin memiliki nilai WHC sebesar $5,68 \mathrm{~g} / \mathrm{g}$ dan nilai OHC sebesar $2,87 \mathrm{~g} / \mathrm{g} .{ }^{4}$

Eceng gondok yang diperoleh dari tempat berbeda akan menghasilkan kandungan kimia yang berbeda. ${ }^{5}$ Secara umum, ketinggian suatu tempat dari permukaan laut (altitude) akan mempengaruhi kandungan kimia tumbuhan karena pengaruh intensitas cahaya dan temperatur. ${ }^{6}$ Kandungan $\alpha$-selulosa dapat mempengaruhi rendemen dan kualitas $\mathrm{Na}-$ CMC hasil sintesis. ${ }^{7}$

Jatinangor merupakan salah satu kecamatan di Kabupaten Sumedang, berupa daerah perbukitan yang berada pada ketinggian 501 hingga 1000 meter diatas permukaan laut. ${ }^{8}$ Sedangkan, Lembang merupakan sebuah daerah yang terletak di sebelah utara kota Bandung, berada di ketinggian antara 1.312 hingga 2.084 meter di atas permukaan laut. ${ }^{9}$

Pada penelitian ini akan dilakukan sintesis dan karakterisasi Na-CMC dari selulosa tanaman eceng gondok yang diperoleh dari dua daerah yang berbeda, yaitu daerah Jatinangor dan Lembang untuk mengetahui karakteristiknya berdasarkan Farmakope Indonesia, dan The Joint FAO/WHO Expert Committee on Food Addictives (JECFA). Selain itu, dilakukan uji statistika komparatif untuk mengetahui apakah terdapat perbedaan nilai WHC dan OHC dari Na-CMC yang disintesis dari selulosa tanaman eceng gondok (Eichhornia crassipes (Mart.) Solms) yang tumbuh di daerah Jatinangor dan Lembang.

\section{Metode}

\section{Alat}

Alat yang digunakan untuk sintesis Na-CMC meliputi timbangan digital (Ohaus Pioneer), oven (Memmert), hotplate magnetic stirrer (Cimarec), ayakan mesh 50, kain penyaring jenis cotton, oven (Heraeus), Fourier Transform Infrared Spectrophotometer (Shimadzu IR Prestige-21), tanur (Thermo Scientific FB1410M-33), pH meter (Mettler Tolledo), Viscotester (Rion VT-04F) dan alat-alat gelas yang umum digunakan di laboratorium Kimia Analitik.

\section{Bahan}

Bahan-bahan yang digunakan dalam penelitian ini adalah eceng gondok yang diperoleh dari Arboretum Universitas Padjadjaran dan kolam di daerah Legok Ciburial, Desa Cikole, Lembang Kabupaten Bandung Barat, akuades, natrium hidroksida $(\mathrm{NaOH})$ teknis (Bratachem), natrium hipoklorit $(\mathrm{NaOCl})$ teknis (Bratachem), kalium dikromat (K2Cr2O7) (Merck), asam sulfat (H2SO4) pekat (Merck), ferro sulfat (Merck), fenantrolin (Merck), ferro ammonium sulfat[(NH4)2Fe(SO4)2.6H2O] (Merck), barium klorida (Merck), isopropil 
alkohol (Bratachem), natrium monokloroasetat $(\mathrm{NaCH} 2 \mathrm{COOCl})$ (Sigma Aldrich), metanol (Bratachem), etanol (Bratachem), asam asetat $(\mathrm{CH} 3 \mathrm{COOH})$ glasial (Bratachem), ammonium hidroksida $(\mathrm{NH} 4 \mathrm{OH})$ (Merck), epiklorohidrin (Sigma Aldrich), dan minyak zaitun (Dougo).

Metode Penelitian

Preparasi Bahan Baku Eceng Gondok

Bahan baku eceng gondok (Eichhornia crassipes (Mart.) Solms) yang diperoleh dari daerah Jatinangor dan Lembang dibuang bagian akarnya, dicuci dengan air kemudian dikeringkan. Tumbuhan eceng gondok dideterminasi di Laboratorium Taksonomi Tumbuhan, Departemen Biologi FMIPA Universitas Padjadjaran.

Eceng gondok dipotong-potong dan dijemur di bawah sinar matahari selama 5-7 hari kemudian dihancurkan menjadi bentuk serbuk kasar. Serbuk dikeringkan kembali dengan oven pada suhu $95^{\circ} \mathrm{C}$ selama 12 jam. Dilakukan pengayakan menggunakan ayakan mesh 50 dan serbuk eceng gondok siap digunakan. ${ }^{1}$

Pengujian Kadar Air dan Kadar Abu dari Serbuk Eceng Gondok

Berat kering botol timbang bertutup ditentukan terlebih dahulu dengan cara memanaskan botol timbang beserta tutupnya dipindahkan ke dalam desikator dan didiamkan selama \pm 10 menit kemudian ditimbang. Pemanasan dan penimbangan diulangi sampai diperoleh berat tetap. Serbuk eceng gondok kering udara dimasukkan ke dalam botol timbang yang telah diketahui beratnya, kemudian serbuknya ditimbang sebanyak 2 gram (W1). Botol timbang yang telah berisi serbuk dimasukkan ke dalam oven dan tutup botol timbangnya dibuka. Dipanaskan selama 3 jam pada suhu $105^{\circ} \mathrm{C}$ $\pm 3^{\circ} \mathrm{C}$. Didinginkan dalam desikator selama 10 menit kemudian hasilnya ditimbang. Pemanasan dan penimbangan diulangi sampai diperoleh berat yang tetap (W2). ${ }^{10}$

Kadar air serbuk eceng gondok dihitung berdasarkan rumus:

$$
\mathrm{x}=\frac{\mathrm{W} 1-\mathrm{W} 2}{\mathrm{~W} 1} \times 100 \%
$$

Keterangan:

$\mathrm{X}=$ kadar air sampel (\%)

$\mathrm{W} 1=$ berat contoh serbuk eceng gondok semula (gram)

W2 = berat kering sampel

Pengujian kadar abu serbuk eceng gondok dilakukan dengan menggunakan metode termogravimetri. Proses pengabuan dilakukan menggunakan tanur pada suhu $600^{\circ} \mathrm{C} .{ }^{10}$

\section{Isolasi $\alpha$-Selulosa dari Eceng Gondok}

Serbuk eceng gondok ditambahkan air sampai dapat merendam bahan dan dididihkan kemudian disaring. Bagian yang tidak larut ditambahkan natrium hidroksida $(\mathrm{NaOH}) 30 \%$ dengan perbandingan serbuk eceng gondok awal dan $\mathrm{NaOH} 30 \%$ adalah 1:40 dan dipanaskan hingga mendidih selama 1 jam, lalu disaring. Residu yang diperoleh dicuci dengan aquades sampai $\mathrm{pH}$ 6-7, kemudian ditambahkan larutan pemutih natrium hipoklorit $(\mathrm{NaOCl}) 12 \%$ hingga merendam residu dan dibiarkan selama 4 jam pada suhu kamar. Residu disaring dan dicuci dengan aquades sampai bau klorin hilang dan dikeringkan pada oven $50^{\circ} \mathrm{C}$ hingga diperoleh berat konstan. Residu kering yang diperoleh dilanjutkan dengan analisis $\alpha$-selulosa. ${ }^{1}$

\section{Analisis Kandungan $\alpha$-Selulosa}

Analisiskandungan $\alpha$-selulosa dilakukan menurut SNI 0444-2009 mengenai cara uji kadar selulosa alfa, beta dan gamma dalam pulp. Corong masir dan botol timbang dipanaskan pada oven dengan suhu $25^{\circ} \mathrm{C}$ $\pm 0,2^{\circ} \mathrm{C}$ hingga beratnya tetap. Kemudian didinginkan dalam desikator hingga suhu kamar dan ditimbang dengan ketelitian 0,5 mg. Sampel uji ditimbang seberat $1,5 \mathrm{~g} \pm$ $0,1 \mathrm{~g}$ dengan ketelitian $0,1 \mathrm{mg}$. Sampel uji ditambahkan $75 \mathrm{~mL}$ larutan $\mathrm{NaOH}$ 17,5\%. waktu dicatat pada saat larutan $\mathrm{NaOH}$ ditambahkan. Ketika pulp telah terdispersi, 
pengaduk diangkat dan pulp yang menempel pada ujung batang pengaduk dibersihkan. Pengaduk dicuci dengan $25 \mathrm{~mL}$ larutan $\mathrm{NaOH} 17,5 \%$ dan ditambahkan ke dalam gelas piala, sehingga total larutan yang ditambahkan ke dalam pulp sebanyak 100 $\mathrm{mL}$. Suspensi pulp diaduk dan disimpan pada suhu $25^{\circ} \mathrm{C} \pm 0,2^{\circ} \mathrm{C}$. Setelah 30 menit dari penambahan pertama $\mathrm{NaOH}$, akuades ditambahkan sebanyak $100 \mathrm{~mL}$ dan diaduk segera. Gelas piala disimpan pada penangas air untuk 30 menit berikutnya sehingga total waktu ekstraksi seluruhnya adalah 60 menit. Setelah 60 menit, suspensi diaduk dengan batang pengaduk dan dituangkan ke dalam corong masir. Filtrat pertama dibuang kemudian filtrat dikumpulkan sekitar $100 \mathrm{~mL}$ dalam labu yang kering dan bersih. Filtrat sebanyak $25 \mathrm{~mL}$ dimasukkan ke dalam labu $250 \mathrm{~mL}$, ditambahkan larutan kalium dikromat 0,5 $\mathrm{N}$ sebanyak $10 \mathrm{~mL}$ dan asam sulfat pekat sebanyak 50 $\mathrm{mL}$. Larutan dipanaskan pada suhu $125^{\circ} \mathrm{C}$ sampai $135^{\circ} \mathrm{C}$ dan dibiarkan tetap panas selama 15 menit. Larutan ditambahkan 50 $\mathrm{mL}$ akuades dan didinginkan pada suhu ruangan. Indikator ferroin ditambahkan sebanyak 2-4 tetes kemudian dititrasi dengan larutan ferro ammonium sulfat $0,1 \mathrm{~N}$ sampai berwarna ungu kecoklatan. Titrasi blanko dilakukan dengan mengganti filtrat pulp dengan $12,5 \mathrm{~mL}$ larutan $\mathrm{NaOH} \quad 17,5 \%$ dan $12,5 \mathrm{~mL}$ aquades. ${ }^{11}$

Kandungan $\alpha$-selulosa dihitung dengan rumus:

$$
X=\frac{6,85(\mathrm{~V} 1-\mathrm{V} 2) \times \mathrm{N} \times 20}{\mathrm{AxW}}
$$

\section{Keterangan:}

$$
\begin{aligned}
\mathrm{X} & =\alpha \text {-Selulosa }(\%) \\
\mathrm{V} 1 & =\text { volume titrasi blanko }(\mathrm{mL}) \\
\mathrm{V} 2 & =\text { volume titrasi pulp }(\mathrm{mL}) \\
\mathrm{N} & =\text { normalitas larutan ferro } \\
& \text { ammonium sulfat } \\
\mathrm{A} \quad= & \text { volume filtrat pulp yang } \\
& \text { dianalisis }(\mathrm{mL}) \\
\mathrm{W} & =\text { berat kering oven contoh uji pulp }
\end{aligned}
$$

Sintesis Na-CMC dari Selulosa Eceng Gondok

Selulosa disuspensikan dalam isopropil alkohol di bawah pengaduk mekanik pada temperatur ruang dan ditambahkan $\mathrm{NaOH}$ 40\%. Campuran diaduk selama 90 menit. Natrium monokloroasetat $(\mathrm{ClCH} 2 \mathrm{COONa})$ kemudian pelan-pelan ditambahkan ke dalam campuran selama 30 menit dan temperatur diatur pada suhu $55^{\circ} \mathrm{C}$ selama 3,5 jam. Setelah itu, metanol 70\% ditambahkan ke dalam reaktor dan campuran dinetralkan dengan asam asetat 90\%. Pereaksi yang digunakan pada sintesis Na-CMC yaitu serbuk $\alpha$-selulosa, isopropil alkohol, $\mathrm{NaOH}$ $40 \%, \mathrm{ClCH} 2 \mathrm{COONa}$, metanol $70 \%$ dan asam asetat $90 \%$ dengan perbandingan berturut-turut adalah $1: 20: 20: 5: 20$ : 15. Na-CMC kemudian disaring dan dicuci sebanyak 6 kali dengan etanol. NaCMC yang telah dicuci etanol kemudian dicuci kembali dengan metanol murni dan dikeringkan menggunakan oven pada suhu $60^{\circ} \mathrm{C}^{7}$

Crosslinking Na-CMC dari Selulosa Eceng Gondok dengan Epiklorohidrin dalam perbandingan 1:10

$\mathrm{Na}-\mathrm{CMC}$ hasil sintesis dari selulosa eceng gondok ditimbang sebanyak 5 gram berat kering, kemudian dicampurkan

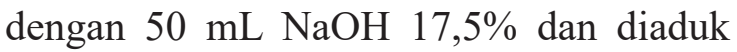
pada suhu $50^{\circ} \mathrm{C}$ selama 20 menit. Perbandingan massa Na-CMC dan Epiklorohidrin yang digunakan adalah 1:10. Epiklorohidrin dengan perbandingan massa 1:1 dicampurkan dengan $\mathrm{NH} 4 \mathrm{OH} 25 \%$. Lalu, campuran tersebut ditambahkan ke dalam sampel. Sampel direfluks selama 4 jam pada suhu $40^{\circ} \mathrm{C}$. Produk crosslink yang tidak larut dikumpulkan, dicuci dengan etanol dan akuades kemudian dikeringkan. Sehingga diperoleh produk crosslinking $\mathrm{Na}-\mathrm{CMC}{ }^{4}$

Karakterisasi Na-CMC Hasil Sintesis

Karakterisasi Na-CMC yang disintesis dari selulosa eceng gondok dilakukan menurut The Joint FAO/WHO Expert 
Committee on Food Addictives (JECFA), ${ }^{12}$ dan Farmakope Indonesia edisi ke-V. ${ }^{13}$ Pemeriksaan karakteristik Na-CMC yang dilakukan meliputi:

1. Pemeriksaan Organoleptis

Pemeriksaan yang dilakukan meliputi pemeriksaan bentuk, warna, bau dan rasa sesuai dengan Farmakope Indonesia Edisi ke-V. ${ }^{13}$

\section{Kelarutan}

$\mathrm{Na} \mathrm{CMC}$ diamati kelarutannya terhadap air, etanol dan eter. ${ }^{13}$

\section{Foam Test (Pembentukan Busa)}

Sampel dibuat bentuk larutan dengan konsentrasi $0,1 \%$ kemudian dikocok kuat-kuat. Pada Na CMC tidak terbentuk lapisan busa pada permukaan larutan. ${ }^{12}$

\section{Pembentukan Endapan}

Tambahkan lebih kurang $1 \mathrm{~g}$ zat pada $50 \mathrm{~mL}$ air sambil diaduk hingga terdispersi homogen. Lanjutkan pengadukan hingga diperoleh larutan jernih. Pada $5 \mathrm{~mL}$ larutan tambahkan 5 mL barium klorida, terbentuk endapan halus putih. ${ }^{13}$

5. Penentuan $\mathrm{pH}$ larutan $\mathrm{Na} \mathrm{CMC} 1 \%$ $\mathrm{Na}$ CMC ditimbang sebanyak 1 gram dan dilarutkan dalam akuades $100 \mathrm{~mL}$ dengan memanaskan pada suhu $60^{\circ} \mathrm{C}$ dan diaduk sampai larut. Setelah larut merata, didinginkan pada suhu ruang. Penetapan $\mathrm{pH}$ dilakukan dengan pH meter. ${ }^{14}$

\section{Susut Pengeringan}

Sampel ditimbang 1-2 gram dalam botol timbang yang telah diketahui beratnya. Dikeringkan pada suhu $105^{\circ} \mathrm{C}$ sampai bobot tetap. Setelah dikeringkan, botol timbang dalam keadaan tertutup dimasukkan ke dalam desikator, didinginkan pada suhu ruang dan ditimbang. ${ }^{12}$

$$
\%=\frac{\text { Kehilangan Berat }}{\text { Berat Sampel }} \times 100 \%
$$

7. Penentuan kandungan $\mathrm{Na}$ dalam $\mathrm{Na}-\mathrm{CMC}$

Penentuan total kandungan natrium dalam Na-CMC dilakukan dengan menggunakan instrumen Atomic Absorption Spectroscopy (AAS). ${ }^{12}$

\section{Penentuan Derajat Substitusi (DS)}

Penentuan derajat substitusi dilakukan dengan menghitung terlebih dahulu kadar natrium dalam Na-CMC dan selajutnya dikalikan dengan faktor pengali. ${ }^{12}$

$$
\mathrm{DS}=\frac{162 \times \% \text { natrium }}{2300-(80 \times \% \text { natrium })}
$$

\section{Water Holding Capacity (WHC)} dan Oil Holding Capacity (OHC)

Akuades dan olive oil $25 \mathrm{~mL}$ ditambahkan masing-masing dengan 1 gram sampel Na-CMC kering, kemudian diaduk dengan pengaduk mekanik sambil diinkubasi pada suhu $40^{\circ} \mathrm{C}$ selama 1 jam. Selanjutnya disentrifugasi kemudian dihitung nilai WHC dan OHC sebagai gram hasil per gram sampel. ${ }^{15}$

\section{Penentuan Viskositas Larutan 1\%}

$\mathrm{Na}$ CMC ditimbang sebanyak 1 gram dan dilarutkan dalam akuades 100 $\mathrm{mL}$ dan dipanaskan pada suhu $25^{\circ} \mathrm{C}$ sambil diaduk sampai larut. Setelah larut merata, didinginkan pada suhu ruang. Penetapan viskositas larutan dilakukan dengan menggunakan viskometer. ${ }^{14}$

\section{Pengujian Kandungan Logam Berat dalam Na-CMC Hasil Sintesis dari Selulosa Eceng Gondok \\ Pengujian kandungan logam berat dalam Na-CMC hasil sintesis dari selulosa eceng gondok dilakukan dengan instrumen Atomic Absorption Spectroscopy (AAS). Logam berat yang diuji adalah timbal $(\mathrm{Pb}){ }^{12}$}


1. Identifikasi Gugus Fungsi Na-CMC dengan Fourier Transform Infrared (FTIR)

Pelet dibuat dari sampel Na-CMC (2-5 mg) digerus bersama dengan $\mathrm{KBr}$ (200-250 mg). Kemudian spektrum inframerah dari sampel Na-CMC direkam dengan FTIR. Transmisi diukur pada bilangan gelombang 4000 $400 \mathrm{~cm}-1.7$

Uji Statistika U Mann-Whitney dengan menggunakan Software SPSS versi 23.0

Uji statistika dilakukan dengan UMannWhitney menggunakan software SPSS versi 23.0 dengan membagi data ke dalam dua kelompok, yaitu kelompok eceng gondok yang berasal dari Jatinangor dan kelompok eceng gondok yang berasal dari Lembang, dimana pada masing-masing kelompok terdapat 6 sampel yang diuji yaitu nilai WHC dari Na-CMC tanpa crosslink dan

\section{Hasil}

Tabel 1. Hasil Uji Susut Pengeringan Simplisia Eceng Gondok

\begin{tabular}{cccc}
\hline $\begin{array}{c}\text { Eceng } \\
\text { Gondok }\end{array}$ & $\begin{array}{c}\text { Berat } \\
\text { Basah } \\
(\mathbf{k g})\end{array}$ & $\begin{array}{c}\text { Berat } \\
\text { Kering } \\
(\mathbf{k g})\end{array}$ & $\begin{array}{c}\text { Susut } \\
\text { pengeringan } \\
(\mathbf{\%})\end{array}$ \\
\hline Jatinangor & 5,19 & 0,492 & 90,52 \\
Lembang & 5,19 & 0,148 & 97,14 \\
\hline
\end{tabular}

Tabel 2. Hasil Pengujian Kadar Air dan Kadar Abu Simplisia Eceng Gondok

\begin{tabular}{ccc}
\hline $\begin{array}{c}\text { Eceng } \\
\text { Gondok }\end{array}$ & $\begin{array}{c}\text { Kadar Air } \\
\mathbf{( \% )}\end{array}$ & $\begin{array}{c}\text { Kadar Abu } \\
\mathbf{( \% )}\end{array}$ \\
\hline Jatinangor & 7,76 & 17,76 \\
Lembang & 7,78 & 19,44 \\
\hline
\end{tabular}

Sementara itu hasil isolasi alfa sellulosa dari eceng gondok Jatinangor dan Lembang ditunjukkan pada Tabel 3 dan 4. Sedangkan hasil sintesis $\mathrm{Na} \mathrm{CMC}$ pad Tabel 5 dan 6 . nilai WHC dari Na-CMC dengan crosslink (1:10).

Hipotesis yang diajukan adalah:

H0 : Tidak terdapat perbedaan nilai WHC yang signifikan diantara kelompok eceng gondok yang berasal dari Lembang dan Jatinangor.

H1 : Terdapat perbedaan nilai WHC yang signifikan diantara kelompok eceng gondok yang berasal dari Lembang dan Jatinangor. dengan menggunakan $\alpha=5 \%$, maka pengambilan keputusan:

1. Jika nilai signifikansi atau Pvalue $>0,05$ maka $\mathrm{H} 0$ diterima dan $\mathrm{H} 1$ ditolak.

2. Jika nilai signifikansi atau Pvalue $<0,05$ maka H0 ditolak dan $\mathrm{H} 1$ diterima.

Perlakuan yang sama dilakukan untuk mengetahui perbedaan nilai $\mathrm{OHC}$ dari Na-CMC dari kelompok eceng gondok yang berasal dari daerah Jatinangor dan kelompok eceng gondok yang berasal dari Lembang.

Tabel 3. Hasil Isolasi $\alpha$-Selulosa Eceng Gondok Jatinangor

\begin{tabular}{cccc}
\hline $\begin{array}{c}\text { Isolasi } \\
\text { ke: }\end{array}$ & $\begin{array}{c}\text { Berat } \\
\text { simplisia } \\
(\mathrm{g})\end{array}$ & $\begin{array}{c}\text { Berat } \\
\alpha \text {-Selulosa } \\
(\mathrm{g})\end{array}$ & $\begin{array}{c}\% \\
\text { Rendemen }\end{array}$ \\
\hline 1 & 10 & 2,6 & 26,00 \\
2 & 20 & 4,1 & 20,50 \\
3 & 20 & 4 & 20,00 \\
4 & 20 & 3,868 & 19,34 \\
5 & 20 & 4,676 & 23,38 \\
& Rata-rata & & 20,80 \\
& SD & & 2,78 \\
\hline
\end{tabular}

Tabel 4. Hasil Isolasi $\alpha$-Selulosa Eceng Gondok Lembang

\begin{tabular}{cccc}
\hline $\begin{array}{c}\text { Isolasi } \\
\text { ke: }\end{array}$ & $\begin{array}{c}\text { Berat } \\
\text { Simplisia } \\
(\mathrm{g})\end{array}$ & $\begin{array}{c}\text { Berat } \\
\alpha \text {-Selulosa } \\
(\mathrm{g})\end{array}$ & $\begin{array}{c}\% \\
\text { Rendemen }\end{array}$ \\
\hline 1 & 20 & 5,3 & 26,50 \\
2 & 10 & 1,7 & 17,00 \\
3 & 20 & 2 & 10,00 \\
4 & 40 & 7,6 & 19,00 \\
5 & 20 & 4,1 & 20,50 \\
& Rata-rata & & 20,80 \\
& SD & & 2,78 \\
\hline
\end{tabular}


Tabel 5. Hasil Sintesis Na-CMC Eceng Gondok Jatinangor

\begin{tabular}{cccc}
\hline $\begin{array}{c}\text { Sintesis } \\
\text { ke: }\end{array}$ & $\begin{array}{c}\text { Berat } \\
\boldsymbol{\alpha} \text {-Selulosa } \\
\text { (g) }\end{array}$ & $\begin{array}{c}\text { Berat } \\
\text { Na-CMC } \\
\text { yang } \\
\text { Dihasilkan } \\
\text { (g) }\end{array}$ & $\begin{array}{c}\% \\
\text { Rendemen }\end{array}$ \\
\hline 1 & 5,00 & 4,64 & 92,80 \\
2 & 5,00 & 4,93 & 98,56 \\
3 & 5,02 & 4,98 & 99,25 \\
& Rata-rata & & 96,87 \\
\hline
\end{tabular}

Tabel 8. Hasil Karakterisasi Na-CMC Hasil Sintesis dariEceng Gondok Jatinangor

\begin{tabular}{|c|c|c|}
\hline Parameter & $\begin{array}{c}\text { Non } \\
\text { Crosslink }\end{array}$ & Crosslink \\
\hline \multicolumn{3}{|l|}{ Organoleptis } \\
\hline Warna & Putih & $\begin{array}{c}\text { Putih } \\
\text { Kekuningan }\end{array}$ \\
\hline Bau & Tidak Berbau & Tidak Berbau \\
\hline Rasa & Tidak Berasa & Tidak Berasa \\
\hline Bentuk & Serbuk & Serbuk \\
\hline \multicolumn{3}{|l|}{ Kelarutan } \\
\hline Air & Terdispersi & Terdispersi \\
\hline Alkohol & Tidak Larut & Tidak Larut \\
\hline Eter & Tidak Larut & Tidak Larut \\
\hline pH & 6,72 & 6,74 \\
\hline $\begin{array}{c}\text { Susut } \\
\text { Pengeringan } \\
(\%) \\
\end{array}$ & 13,02 & 0,47 \\
\hline Foam Test & Negatif & Negatif \\
\hline Pengendapan & +++ & + \\
\hline \multirow{3}{*}{ WHC (g/g) } & (1) 29,38 & (1) 5,08 \\
\hline & (2) 28,60 & (2) 5,15 \\
\hline & (3) 29,01 & (3) 5,16 \\
\hline \multirow{3}{*}{ OHC (g/g) } & (1) 8,67 & (1) 4,22 \\
\hline & (2) 8,84 & (2) 4,24 \\
\hline & (3) 8,42 & (3) 4,24 \\
\hline Logam Pb & - & - \\
\hline $\begin{array}{c}\text { Kadar Na } \\
(\%)\end{array}$ & 2,654 & 0,559 \\
\hline $\begin{array}{c}\text { Derajat } \\
\text { Substitusi }\end{array}$ & 0,205 & 0,040 \\
\hline
\end{tabular}

Tabel 6. Hasil Sintesis Na-CMC Eceng Gondok Lembang

\begin{tabular}{cccc}
\hline $\begin{array}{c}\text { Sintesis } \\
\text { ke: }\end{array}$ & $\begin{array}{c}\text { Berat } \\
\boldsymbol{\alpha - S e l u l o s a} \\
(\mathbf{g})\end{array}$ & $\begin{array}{c}\text { Berat } \\
\text { Na-CMC } \\
\text { yang } \\
\text { Dihasilkan } \\
\text { (g) }\end{array}$ & $\begin{array}{c}\% \\
\text { Rendemen }\end{array}$ \\
\hline 1 & 5,00 & 3,93 & 76,80 \\
2 & 5,01 & 4,64 & 92,72 \\
3 & 5,00 & 4,28 & 85,58 \\
& Rata-rata & & 85,03 \\
\hline
\end{tabular}

Tabel 9. Hasil Karakterisasi Na-CMC Hasil Sintesis dari Eceng Gondok Lembang

\begin{tabular}{|c|c|c|}
\hline Parameter & $\begin{array}{c}\text { Non } \\
\text { Crosslink }\end{array}$ & Crosslink \\
\hline \multicolumn{3}{|l|}{ Organoleptis } \\
\hline Warna & Putih & $\begin{array}{c}\text { Putih } \\
\text { Kekuningan }\end{array}$ \\
\hline Bau & Tidak Berbau & Tidak Berbau \\
\hline Rasa & Tidak Berasa & Tidak Berasa \\
\hline Bentuk & Serbuk & Serbuk \\
\hline \multicolumn{3}{|l|}{ Kelarutan } \\
\hline Air & Terdispersi & Terdispersi \\
\hline Alkohol & Tidak Larut & Tidak Larut \\
\hline Eter & Tidak Larut & Tidak Larut \\
\hline pH & 6,61 & 6,82 \\
\hline $\begin{array}{c}\text { Susut } \\
\text { Pengeringan } \\
(\%) \\
\end{array}$ & 10,57 & 1,87 \\
\hline Foam Test & Negatif & Negatif \\
\hline Pengendapan & +++ & + \\
\hline \multirow{3}{*}{ WHC (g/g) } & (1) 22,14 & (1) 4,92 \\
\hline & (2) 22,12 & (2) 4,95 \\
\hline & (3) 22,99 & (3) 4,82 \\
\hline \multirow{3}{*}{ OHC (g/g) } & (1) 8,67 & (1) 3,71 \\
\hline & (2) 7,35 & (2) 3,75 \\
\hline & (3) 7,28 & (3) 3,75 \\
\hline Logam $\mathbf{P b}$ & - & - \\
\hline $\begin{array}{c}\text { Kadar Na } \\
(\%)\end{array}$ & 1,881 & 0,192 \\
\hline $\begin{array}{c}\text { Derajat } \\
\text { Substitusi }\end{array}$ & 0,141 & 0,013 \\
\hline
\end{tabular}


Tabel 7. Hasil Crosslink Na-CMC

\begin{tabular}{cccc}
\hline Na-CMC & $\begin{array}{c}\text { Berat } \\
\text { Na- } \\
\text { CMC } \\
\text { (g) }\end{array}$ & $\begin{array}{c}\text { Berat } \\
\text { Na-CMC } \\
\text { Crosslink } \\
(\mathbf{g})\end{array}$ & \% Rendemen \\
\hline Jatinangor & 2,00 & 8,8 & 439,14 \\
Lembang & 2,00 & 4,36 & 221,81 \\
\hline
\end{tabular}

\section{Pembahasan}

Hasil Preparasi Bahan Baku Eceng Gondok (Eichhornia crassipes (Mart.) Solms)

Bahan baku eceng gondok (Eichhornia crassipes (Mart.) Solms) diperoleh dari dua tempat, yaitu sungai di Arboretum Universitas Padjadjaran, Sumedang dan kolam di daerah Lembang, Kabupaten Bandung Barat. Hasil determinasi tumbuhan menunjukkan bahwa kedua tanaman tersebut benar merupakan eceng gondok (Eichhornia crassipes (Mart.) Solms).

Tanaman eceng gondok dibuang akar dan daunnya kemudian dicuci dengan air hingga bersih dari kotoran dan lumpur. Eceng gondok kemudian dirajang menjadi ukuran yang lebih kecil. Perajangan ini dilakukan untuk memperkecil ukuran, memperluas permukaan dan mengurangi sifat eceng gondok yang voluminus. Eceng gondok yang telah dirajang kemudian dijemur di bawah sinar matahari selama 5-7 hari. Bahan baku eceng gondok yang telah kering kemudian diuji susut pengeringan. Eceng gondok segar memiliki kandungan air hingga $90 \% .{ }^{5}$ Hasil uji susut pengeringan dapat dilihat pada Tabel 1.

Hasil Pengujian Kadar Air dan Kadar Abu dari serbuk Eceng Gondok

Pengujian kadar air simplisia bertujuan untuk mencapai kadar air kurang dari 10\%. ${ }^{9}$ Kecuali dinyatakan dalam literatur seperti

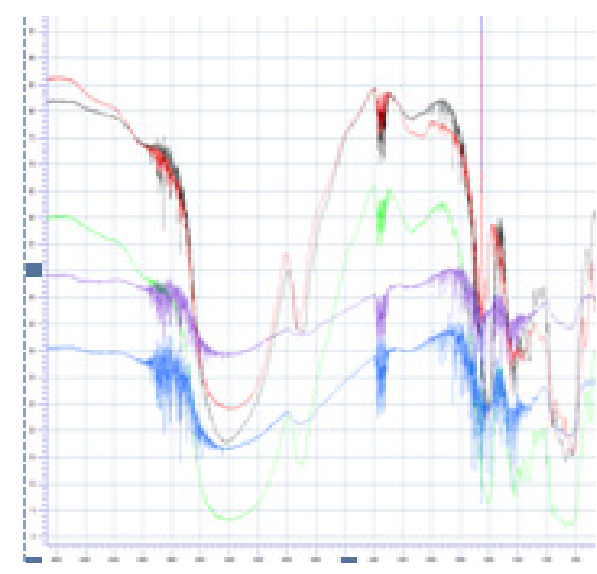

Gambar 1. Overlay Spektrum Inframerah $\mathrm{Na}-\mathrm{CMC}$

Materia Medika Indonesia terutama untuk tumbuhan yang akan dijadikan obat.

Pengujian kadar abu dilakukan dengan menggunakan metode termogravimetri. Pengabuan dengan tanur menyisakan mineral dan bahan anorganik. Bahan baku eceng gondok yang diuji memiliki kadar abu sebesar 17,76\% dan 19,44\%. Kadar abu yang tinggi ini berkaitan dengan fungsi tumbuhan eceng gondok sebagai fitoremediator. Kadar abu dalam suatu bahan dapat berkaitan dengan kandungan logam di dalamnya. Eceng gondok efektif menyerap dan menyisihkan logam pada limbah industri. ${ }^{16}$ Oleh karena itu dilakukan uji kadar logam $\mathrm{Pb}$ sebagai salah syarat uji kualitas Na-CMC, dan menunjukkan bahwa Na-CMC yang dihasilkan dari sintesis alfa selulosa eceng gondok dari daerah Jatinangor dan Lembang tidak mengandung logam $\mathrm{Pb}$ (Tabel 8). Kadar abu dari bahan baku eceng gondok tersebut juga lebih kecil dari yang pernah dilaporkan sebelumnya yaitu $52,07 \%{ }^{5}$

Hasil Isolasi $\alpha$-Selulosa dari Eceng Gondok

Proses isolasi $\alpha$-selulosa terbagi dalam tiga tahap, yaitu pre-hidrolisis, delignifikasi dan bleaching. Tahap pre-hidrolisis yaitu pemasakan serbuk eceng gondok dengan akuades hingga mendidih selama 15 menit bertujuan untuk mempercepat pemisahan hemiselulosa.. Delignifikasi bertujuan untuk melarutkan lignin sehingga mempermudah 
pemisahan lignin dan selulosa. $\mathrm{NaOH}$ $30 \%$ dapat melarutkan bentuk selulosa lain seperti $\beta$-selulosa, $\gamma$-selulosa, hemiselulosa, dan holoselulosa sehingga yang tersisa adalah $\alpha$-selulosa. ${ }^{17}$ Residu yang tersisa setelah proses penyaringan dicuci hingga $\mathrm{pH}$ netral kemudian ditambahkan dengan larutan natrium hipoklorit hingga terendam seluruhnya dan dibiarkan selama 4 jam.

Derajat putih selulosa dapat ditingkatkan dengan penghilangan warna lignin, salah satunya dengan hipoklorit. Pada proses bleaching terjadi dua reaksi yaitu klorinasi dan oksidasi. Reaksi ini menyebabkan perubahan warna selulosa dari coklat menjadi putih dan lignin menjadi mudah larut dalam air sehingga saat pencucian, lignin akan terbawa oleh air dan tersisa $\alpha$-selulosa. ${ }^{17} \quad \alpha$-Selulosa dicuci dengan menggunakan akuades hingga bau klorin hilang. $\alpha$-Selulosa yang telah bebas dari klorin ditandai dengan tidak terbentuknya endapan putih $\mathrm{AgCl}$ pada air sisa pencucian ketika ditambahkan larutan $\mathrm{AgNO}_{3}$. $\alpha$-Selulosa kemudian dikeringkan dengan oven pada suhu $50^{\circ} \mathrm{C} .{ }^{4}$

Penggunaan $\mathrm{NaOH}$ dan $\mathrm{Na}_{2} \mathrm{SO}_{4}$ memberikan hasil $\alpha$-selulosa yang relatif kecil karena $\mathrm{NaOH}$ mempunyai $\mathrm{pH}$ yang besar $(\mathrm{pH}=14)$ sehingga $\alpha$-selulosa yang larut akan terbuang saat pencucian. Dapat digunakan $\mathrm{Na}_{2} \mathrm{SO}_{3}$ sebagai pereaksi alternatif untuk tahap delignifikasi. ${ }^{17}$

\section{Hasil Analisis Kandungan $\alpha$-Selulosa}

Analisis kandungan $\alpha$-selulosa dilakukan sesuai dengan SNI 0444-2009 mengenai cara uji kadar alfa, beta, dan gamma dalam pulp. Dimana digunakan titrasi untuk menentukan kandungan $\beta$-selulosa dan $\gamma$-selulosa. ${ }^{10}$

Kalium dikromat $\left(\mathrm{K}_{2} \mathrm{Cr}_{2} \mathrm{O}_{7}\right)$ berlebih dalam suasana asam dan mendidih dapat mengoksidasi selulosa. ${ }^{4} \quad$ Kelebihan $\mathrm{K}_{2} \mathrm{Cr}_{2} \mathrm{O}_{7}$ tersebut kemudian dititrasi dengan menggunakan larutan ferro ammonium sulfat (FAS). Indikator feroin digunakan untuk menentukan titik akhir titrasi dimana perubahan warna terjadi dari hijau menjadi ungu. ${ }^{10}$

Didapatkan kandungan $\alpha$-selulosa ratarata dari Jatinangor sebesar $76,53 \%$ dan dari Lembang sebesar 71,35 \% dimana kadar ini lebih tinggi dari pengujian yang dilakukan oleh Joedodibroto (1983) yaitu sebesar 64,51\%.18 Semakin besar konsentrasi $\mathrm{NaOH}$ maka $\alpha$-selulosa yang diperoleh semakin besar disebabkan jumlah yang larut selain alfa selulosa semakin besar. ${ }^{17}$

\section{Hasil Sintesis Na-CMC dari Selulosa Eceng Gondok}

Tahapan sintesis Na-CMC terdiri dari alkalisasi, karboksimetilasi, netralisasi, pencucian dan pengeringan. ${ }^{19}$ Isopropil alkohol berfungsi sebagai media untuk mendispersikan selulosa, menyeragamkan reaksi, menambah derajat substitusi, menaikkan laju kinetik reaksi dan sebagai media pertukaran panas. ${ }^{1}$ Isopropil alkohol juga berperan sebagai pelarut inert yang berperan sebagai swelling agent dan sebagai pengencer yang memfasilitasi $\mathrm{NaOH}$ untuk berpenetrasi dengan baik pada selulosa. ${ }^{7}$

Penambahan $\mathrm{NaOH} 40 \%$ menghasilkan alkali selulosa. Proses sintesis dilanjutkan dengan karboksimetilasi, yaitu penambahan natrium monokloroasetat $\left(\mathrm{ClCH}_{2} \mathrm{COONa}\right)$ dan pengadukan selama 3,5 jam pada suhu $55^{\circ} \mathrm{C}$. Pada tahap ini terjadi pula pembentukan produk samping berupa natrium glikolat dan natrium klorida. ${ }^{1}$

Metanol 70\% ditambahkan ke dalam campuran untuk memisahkan Na-CMC dari produk sampingnya. Asam asetat $90 \%$ ditambahkan untuk menetralkan produk karena proses reaksi berjalan pada suasana basa. Na-CMC yang telah dinetralkan kemudian dicuci dengan etanol 96\% dan metanol murni untuk menghilangkan sisa asam glikolat dan pengotor lain. Na-CMC yang sudah bersih kemudian di keringkan dengan menggunakan oven pada suhu $60^{\circ} \mathrm{C}$ selama 24 jam.

Konsentrasi $\mathrm{NaOH}$ yang digunakan pada proses alkalisasi selulosa berpengaruh terhadap Na-CMC yang dihasilkan. Jumlah $\mathrm{Na}-\mathrm{CMC}$ semakin menurun dengan 
peningkatan konsentrasi NaOH.20 Kandungan $\alpha$-selulosa yang lebih tinggi memberikan rendemen $\mathrm{Na}-\mathrm{CMC}$ hasil sintesis lebih tinggi7, sehingga rendemen dari eceng gondok Jatinangor lebih tinggi.

Hasil Crosslinking Na-CMC dari Selulosa Eceng Gondok dengan Epiklorohidrin dalam perbandingan 1:10

Pereaksi yang digunakan pada tahap crosslink adalah $\mathrm{Na}-\mathrm{CMC}$, campuran $\mathrm{NH} 4 \mathrm{OH}$ - epiklorohidrin (1:1) dengan perbandingan 1:10. Perbandingan tersebut merupakan hasil optimasi dimana perbandingan 1:10 memberikan hasil karakterisasi yang paling baik. $^{4}$ Hasil crosslink Na-CMC dapat dilihat pada tabel 7.

Hasil Karakterisasi Na-CMC dari Selulosa Eceng Gondok

Karakterisasi Na-CMC yang disintesis dari selulosa eceng gondok dilakukan menurut The Joint FAO/WHO Expert Committee on Food Addictives (JECFA), ${ }^{12}$ Farmakope Indonesia edisi $\mathrm{V}^{13}$ dan Handbook of Pharmaceutical Excipient. ${ }^{2}$

Secara organoleptis Na-CMC hasil sintesis dan hasil crosslink memiliki karakter yang sama seperti tercantum pada Farmakope Indonesia edisi V. ${ }^{13}$

Susut pengeringan (loss on drying) berkaitan dengan kandungan air pada serbuk Na-CMC. Farmakope Indonesia edisi $V^{13}$ dan JECFA $^{12}$ mempersyaratkan susut pengeringan tidak lebih dari $10 \%$. $\mathrm{Na}-\mathrm{CMC}$ baku dan hasil sintesis yang tidak di crosslink menunjukkan nilai susut pengeringan lebih dari $10 \%$.

Pengujian viskositas larutan $\mathrm{Na}-\mathrm{CMC}$ memberikan hasil untuk Na-CMC baku sebesar $40 \mathrm{mPas}$, Na-CMC non crosslink dan crosslink dari Jatinangor berturutturut adalah sebesar $60 \mathrm{mPas}$ dan $35 \mathrm{mPas}$ sedangkan untuk Na-CMC non crosslink dan crosslink dari Lembang berturut-turut adalah sebesar $50 \mathrm{mPas}$ dan $30 \mathrm{mPas}$. Viskositas larutan Na-CMC 1\% berkisar antara 5-2000 mPas (5-2000 cP). ${ }^{2}$
Hasil identifikasi spektrum inframerah sampel $\mathrm{Na}-\mathrm{CMC}$ hasil sintesis maupun hasil crosslink identik dengan spektrum Na-CMC baku. Puncak serapan pada bilangan gelombang $3391,85 \mathrm{~cm}^{-1}$ hingga $3434,77 \mathrm{~cm}^{-1}$ mengindikasikan adanya gugus -OH. Gugus -OH memberikan serapan pada bilangan gelombang 3800$2700 \mathrm{~cm}^{-1}$. Kemudian serapan pada 2894,21 $\mathrm{cm}^{-1}$ hingga 2922,18 $\mathrm{cm}^{-1}$ mengindikasikan adanya gugus $-\mathrm{C}-\mathrm{H}$ alifatik. Ikatan $\mathrm{C}-\mathrm{H}$ pada rantai alifatik memberikan serapan pada bilangan gelombang $3000-2850 \mathrm{~cm}^{-1}$. Puncak serapan pada bilangan gelombang $1601,89 \mathrm{~cm}^{-1}$ hingga $1641,92 \mathrm{~cm}^{-1}$ pada sampel mengindikasikan adanya gugus karbonil. Ikatan $\mathrm{C}=\mathrm{O}$ memberikan serapan pada bilangan gelombang 1850-1600 $\mathrm{cm}^{-1}$. Bending pada bilangan gelombang $1418,17 \mathrm{~cm}^{-1}$ hingga $1464,95 \mathrm{~cm}^{-1}$ pada sampel mengindikasikan adanya ikatan -C-H alifatik. Sedangkan puncak pada bilangan gelombang $1017,48 \mathrm{~cm}^{-1}$ hingga $1064,23 \mathrm{~cm}^{-1}$ mengindikasikan adanya ikatan glikosida (-C-O) ${ }^{21}$ Gugus karboksil sebagai garam ditunjukkan dengan puncak pada $1600-1640 \mathrm{~cm}^{-1}$ dan $1400-1450 \mathrm{~cm}^{-1}$. Puncak serapan inilah yang membedakan selulosa dengan $\mathrm{Na}-\mathrm{CMC}^{7}$

Hasil pengujian statistika dengan menggunakan Mann-Whitney $U$ test menunjukkan bahwa P-value untuk WHC bernilai lebih kecil dari 0,05. Dengan demikian makaH0 ditolak. Kesimpulanyang dapat diambil adalah terdapat perbedaan nilai WHC yang signifikan diantara kelompok eceng gondok yang berasal dari Lembang dan Jatinangor. Sementara itu, $\mathrm{P}$-value untuk $\mathrm{OHC}$ bernilai lebih besar dari 0,05 . Dengan demikian maka $\mathrm{H} 0$ diterima. Kesimpulan yang dapat diambil adalah tidak terdapat perbedaan nilai $\mathrm{OHC}$ yang signifikan diantara kelompok eceng gondok yang berasal dari Lembang dan Jatinangor.

Nilai WHC yang berbeda signifikan dapat dipengaruhi oleh berbagai faktor. Salah satunya kandungan $\alpha$-selulosa. $\alpha$-Selulosa merupakan bahan baku utama pembuatan Na-CMC. Semakin besar 
kandungan $\alpha$-selulosa maka semakin banyak Na-CMC yang terbentuk. ${ }^{7}$ Hasil uji statistika komparatif menunjukkan bahwa kandungan $\alpha$-selulosa dari eceng gondok Jatinangor dan eceng gondok $\alpha$-selulosa berbeda signifikan ditandai dengan $p$ value $<0,05$.

Nilai WHC tergantung pada interaksi antara air dan $\mathrm{Na}-\mathrm{CMC}$, sisi aktif gugus - $\mathrm{OH}$ dan kondisi lingkungan. Variasi nilai WHC dapat juga dipengaruhi oleh konformasi struktur Na-CMC. Struktur yang seragam dengan berbagai pori-pori kecil mungkin akan menghasilkan daya serap yang lebih dan retensi air yang lebih baik daripada struktur kasar dengan pori-pori besar. Sifat swelling dari Na-CMC tergantung pada rasio matriks dan pelarut, temperatur inkubasi dan lama waktu inkubasi. Temperatur dan lama inkubasi memberikan efek yang paling signifikan pada nilai WHC. ${ }^{22}$

\section{Simpulan}

Na-CMC hasil sintesis dari selulosa eceng gondok yang tumbuh di daerah Jatinangor dan Lembang telah memenuhi beberapa kriteria yang dipersyaratkan oleh Farmakope Indonesia edisi V, JECFA, dan Handbook of Pharmaceutical Excipient yaitu organoleptis, kelarutan, foam test, pembentukan endapan, viskositas dan kandungan logam berat. Parameter yang belum memenuhi kriteria adalah susut pengeringan, kandungan natrium dan derajat substitusi, dimana pada susut pengeringan melebihi nilai yang dipersyaratkan sedangkan untuk kandungan natrium dan derajat substitusi lebih kecil dari nilai yang dipersyaratkan namun masih lebih baik dari Na-CMC baku yang digunakan.

Terdapat perbedaan yang signifikan secara statistika nilai WHC, namun tidak terdapat perbedaan yang signifikan secara statistika dari Na-CMC yang disintesis dari selulosa tanaman eceng gondok (Eichhornia crassipes (Mart.) Solms.) yang tumbuh di daerah Jatinangor dan Lembang.

\section{Daftar Pustaka}

1. Musfiroh, I, Hasanah A.N, Budiman I. The Optimization of Sodium Carboxymethyl Cellulose (Na-CMC) Synthesized from Water Hyacinth (Eichhornia crassipes (Mart.) Solm) Cellulose. RJPBCS. 2013; 4: 10921099.

2. Rowe, Raymond C., Sheskey P. J., Quinn M. E. 2009. Handbook of Pharmaceutical Excipients 6th ed. London: Pharmaceutical Press.

3. Imerson, A. 2009. Food Stabiliser, Thickeners, and Gelling Agents. London: John Wiley \& Sons Publisher.

4. Hasanah A.N, Elyani I, Sriwidodo, Muchtaridi, Muhtadi A, Musfiroh I. Epichlorohydrin as Crosslinking Agent for Synthesis of Carboxymethyl Cellulose Sodium (Na-CMC) as Pharmaceutical Excipient from Water Hyacinth (Eichorrnia Crassipes L.). Int. J. Chem. Sci. 2015; 13(3): 1227-37.

5. Gunnarsson C.C and C.M. Petersen. 2007. Water Hyacinths as A Resource in Agriculture and Energy Production: A Literature Review. Waste Management. 27: 117-129.

6. Artanti, A. N., Nikmah, W. R., Setiawan, D. H., Prihapsara, F. 2016. Perbedaan Kadar Kafein Daun Teh (Camellia sinensis (L.) Kuntze) Berdasarkan Status Ketinggian Tempat Tanam dengan Metode HPLC. JPSC. 01: 3744.

7. Latif,A., Anwar, and S. Noor. 2007. TwoStep Synthesis and Characterization of Carboxymethylcellulose from Rayon Grade Wood Pulp and Cotton Linter. Jour. Chem. Soc. Pak. 29(2): 143-150.

8. Badan Pusat Statistik Kabupaten Sumedang. 2010. Kabupaten Sumedang dalam Angka Tahun 2010. Sumedang: BPS Kabupaten Sumedang

9. Balai Besar Pelatihan Pertanian Lembang. 2014. Kondisi. Geografis Lembang. Tersedia di: www.bbpplembang.info/index.php/profil/sekilas- 
bbpp-lembang/kondisi-geografis [Diakses tanggal 2 November 2015].

10. Sholikhah FS dan Nisa FC. Cookies Beras Pratanak (Kajian Proporsi Tepung Beras Pratanak dengan Tepung Terigu dan Penambahan Shortening). Jurnal Pangan dan Agroindustri. 2015; 3 (3): 1180-91.

11. Standar Nasional Indonesia. 2009. Cara Uji Kadar Selulosa Alfa, Beta, dan Gamma dalam Pulp (SNI 0444:2009). Jakarta: Badan Standarisasi Nasional.

12. Joint FAO/WHO Expert Committee on Food Additives. 2011. Compendium of Food Additive Specifications. [diunduh 9 November 2015]. Tersedia dari http:// www.fao.org/docrep/014/i2358e/ i2358e00.pdf.

13. Departemen Kesehatan Republik Indonesia. 2014. Farmakope Indonesia Edisi V. Jakarta: Departemen Kesehatan Republik Indonesia.

14. Deshmukh, Swati, Kaushal, B., Ghode, S., Formulations and Evaluation of Herbal Shampoo and Comparative Studies with Herbal Marketed Shampoo. Int J Pharm Bio Sci. 2012; 3(3): 638645.

15. Hutomo, G., Djagal W.M., Sri A., and Supriyanto. 2012. Synthesis and Characterization of Sodium Carboxymethyl Cellulose from Pod Husk of Cacao (Theobroma cacao L.). African Journal of Food Science. 6(6): 180-185.

16. Sumiyati, S. dan Mochtar Hadiwidodo. 2007. Pemanfaatan Eceng Gondok (Eichhornia crassipes (Mart.) Solms.) dalam Penyisihan Logam Berat Chrom (Cr) Pada Limbah Elektroplating. Jurnal Teknik 28(1): 34-42.
17. Sumada K, Tamara PE, dan Alqani F. Kajian Proses Isolasi $\alpha$-selulosa dari Limbah Batang Tanaman Manihot esculenta Crantz yang Efisien. Jurnal Teknik Kimia. 2011; 5 (2): 434-438.

18. Joedibroto, R. Prospek Pemanfatan Eceng Gondok dalam Industri Pulp dan Kertas. Berita Selulosa. 1983; 19(1) : 3-7.

19. Nisa, D. dan Widya Dwi R. Pemanfaatan Selulosa dari Kulit Buah Kakao (Teobroma cacao L.) Sebagai Bahan Baku Pembuatan CMC (Carboxymethyl Cellulose). Jurnal Pangan dan Agroindustri. 2014; 2(3): 34-43.

20. Ismail, N.M, A. Bono, A.C.R Valintinus, S. Nilus, and L.M. Chng. Optimization of Reaction Conditions for Preparing Carboxymethylcellulose. J. Applied Sci. 2010; 10 (21): 2530-2536.

21. Signh RK, and Singh AK. Optimization of Reaction Condition for Preparation Carboxymethyl Cellulose for Corn Cobic Agriculture Waste. Waste Biomass Valor. 2013; 4: 129-137.

22. Mirhosseini H. and B.T. Amid. Influence of Chemical Extraction Conditions on the Physicochemical and Functional Properties of Polysaccharide Gum from Durian (Durio zibethinus) Seed. Molecules. 2012; 17:6465-6480. 